\title{
Effects of Environmental Temperature on Life Tables of Rhodnius neivai Lent, 1953 (Hemiptera: Reduviidae) under Experimental Conditions
}

\author{
Daniel R Cabello
}

Departamento de Biología, Facultad de Ciencias, Universidad de Los Andes, Mérida, 5101 Venezuela

Changes in life tables of Rhodnius neivai due to variations of environmental temperature were studied, based on nine cohorts. Three cohorts were kept at $22^{\circ} \mathrm{C}$, three at $27^{\circ} \mathrm{C}$ and three at $32^{\circ} \mathrm{C}$. Cohorts were censused daily during nymphal instars and weekly in adults. Nine complete horizontal life tables were built. A high negative correlation between temperature and age at first laying was registered $(\mathrm{r}=-0,84)$. Age at maximum reproduction was significantly lower at $32^{\circ} \mathrm{C}$. Average number of eggs/ female/week and total eggs/female on its life time were significantly lower at $22^{\circ} \mathrm{C}$. Total number of egg by cohort and total number of reproductive weeks were significantly higher at $27^{\circ} \mathrm{C}$. At $32^{\circ} \mathrm{C}$, generational time was significantly lower. At $27^{\circ} \mathrm{C}$ net reproductive rate and total reproductive value were significantly higher. At $22^{\circ} \mathrm{C}$, intrinsic growth, finite growth and finite birth rates were significantly lower. At $22^{\circ} \mathrm{C}$, death instantaneous rate was significantly higher.

Key words: temperature - vital statistics - Triatominae - Rhodnius neivai - Venezuela

From the beginning of the decade of 70 , life tables have been developed for several species of triatomines and population characteristics have been determined (Rabinovich 1972a,b, Feliciangeli \& Rabinovich 1985, Cabello et al. 1987, Guarneri et al. 1998); however, these works have not considered the effect of different environmental temperatures on life tables of a particular triatomine species.

Rhodnius neivai Lent (1953) has a restricted geographic distribution, limited to arid areas in center western Venezuela (Machado-Allison \& Ramírez Pérez 1967) and northeastern Colombia (Lent \& Wygodzinsky 1979), usually in human dwelling (Lent \& Jurberg 1969). Although it has been considered of little importance as Chagas disease vector, because of its aggressive behavior, its vital statistics have been studied (Cabello et al. 1987) and concluded that it has a wide ecologic valence.

In this work, changes on vital statistics of $R$. neivai, reared under different environmental temperatures were studied to evaluate its adaptation capacity.

\footnotetext{
This work was partially supported by the Consejo de Desarrollo Científico y Humanístico (CDCHT) from de Universidad de Los Andes, Mérida, Venezuela.

Fax: +58-74-401286. E-mail: cabellod@ciens.ula.ve Received 1 December 1998

Accepted 10 May 1999
}

\section{MATERIALS AND METHODS}

Vital statistics described in this study were based on nine cohorts constituted by 100 recently laid eggs ( 0 to $48 \mathrm{hr}$ old) each one; these were kept in $150 \mathrm{~cm}^{3}$ glass containers until all viable eggs hatched; then, all 1st instar nymphs were transferred to nine 3,785 1 broad mouth jars, covered with nylon mesh and provided with vertically placed strips of paper to allowed insects climbing to the jar tops at feeding time and giving them resting places and laying sites. Throughout their development, even during the egg stage, three cohorts were kept at $22^{\circ} \mathrm{C}$, three at $27^{\circ} \mathrm{C}$ and other three at $32^{\circ} \mathrm{C}$.

Cohorts were fed three times a week, during $30 \mathrm{~min}$, using hens placed on a wooden box with holes at the bottom, through which the cohort top jars could be inserted (Gómez Núñez \& Fernández 1963). Bugs climbed to the top and fed through nylon mesh. The cohorts were censused daily during the nymphal instars and weekly in the adults. Daily, the number of dead individuals identified by their nymphal instar, and by sex if adults was checked. Weekly, eggs laid by each female were counted and maintained during five weeks; after this time, number of 1st instar nymphs alive was counted to obtain age-specific fertility. Animals were followed until death of the last adult individual.

The weekly death schedule provided the necessary information to construct nine complete horizontal life tables (Deevey 1947). To carry out the calculations, the method of Dublin et al. (1949) 
was followed. For the definitions of the components of life tables and its formulae, the criteria of Rabinovich (1972a) was followed.

This mortality schedule, coupled with female age-specific fertility, was used to calculate intrinsic rate of natural increase, net reproductive rate, instantaneous birth and death rates (Birch 1948), and age-specific reproductive value (Fisher 1930). All statistics comparisons were based on analysis of variance.

\section{RESULTS}

Life cycle characteristics - The egg eclosion rate was higher than $92 \%$ with an incubation period varying between 12.9 and 24.1 days. Between 53 and 76 nymphs completed the development to the adult stage with an egg-to-adult development time ranging between 68.9 and 118 days (Table I). Table II shows a summary of some life cycle characteristics. At $27^{\circ} \mathrm{C}$ all these characteristics were significantly higher $(p<0.05)$ than at $22^{\circ} \mathrm{C}$ and $32^{\circ} \mathrm{C}$. Adult longevity was calculated simply from the frequency table of the number of weeks live by each individual; it is expressed for the total populations. At $27^{\circ} \mathrm{C}$, it was much greater than at $22^{\circ} \mathrm{C}$ and $32^{\circ} \mathrm{C}$; same relation was determined for life expectancy of egg and adult stages.

Life expectancy - At $22^{\circ} \mathrm{C}$ and $27^{\circ} \mathrm{C}$, it reached a maximum during the 2nd instar, peaks were 30.7 at the age of seven weeks and 46.3 at four weeks respectively. In both temperatures, an increase in life expectancy was registered after egg hatching and before the end of the 2 nd nymphal instar. Then, a constant decline with a regular slope for the rest of nymphal instars and more than 30 weeks of the adult stage was observed; thereafter it dropped linearly with small rises until arriving zero at 68 and 79 weeks of age (Fig. 1).

At $32^{\circ} \mathrm{C}$, it reached a maximum of 21.6 at the age of 11 weeks, i.e., just at the beginning of molting to adult. A slight increase in life expectancy was registered from egg hatching to just after molting to adult. Then, a constant decline with a almost regular slope for more than 30 weeks of the adult stage was observed; thereafter it dropped linearly until arriving zero at 53 weeks of age (Fig. 1).

Survival - In Fig. 2, age-specific mortality is expressed as $1_{x}$, i.e., survival, the probability of being alive at age $\mathrm{x}$. In cohorts fed at $27^{\circ} \mathrm{C}$, it showed a relatively steep slope up to the 1 st nymphal instar, and remained static for the rest of the nymphal instars and the first 25 weeks of the adult stage. At $22^{\circ} \mathrm{C}$, in the 1st and $2 \mathrm{nd}$ nymphal instars, survival showed an abrupt drop, then it followed a very gentle decrease during the $3 \mathrm{rd}$, 4 th and 5th nymphal instars and the first few weeks of the adult stage. At $32^{\circ} \mathrm{C}$, survival showed a constant decline with a steep slope during the five nymphal instars. In any temperature, during the adult stage, it continued declining showing a fairly

TABLE I

Egg to adult development cycle of Rhodnius neivai at three different temperatures (duration in days) $($ mean \pm SE)

\begin{tabular}{|c|c|c|c|c|c|c|}
\hline \multirow[b]{2}{*}{ Stage } & \multicolumn{2}{|c|}{$22^{\circ} \mathrm{C}$} & \multicolumn{2}{|c|}{$27^{\circ} \mathrm{C}$} & \multicolumn{2}{|c|}{$32^{\circ} \mathrm{C}$} \\
\hline & Mean \pm SE & $n$ & Mean \pm SE & $n$ & Mean \pm SE & $n$ \\
\hline Egg-NI & $24.1 \pm 0.2$ & 93 & $19.9 \pm 0.1$ & 92 & $12.9 \pm 0.1$ & 96 \\
\hline NI-NII & $17.6 \pm 7.2$ & 74 & $10.3 \pm 3.1$ & 81 & $10.4 \pm 4.3$ & 80 \\
\hline NII-NIII & $17.8 \pm 5.3$ & 73 & $10.0 \pm 2.3$ & 78 & $8.7 \pm 2.5$ & 71 \\
\hline NIII-NIV & $15.5 \pm 5.2$ & 73 & $11.4 \pm 4.2$ & 78 & $9.5 \pm 2.6$ & 66 \\
\hline NIV-NV & $16.8 \pm 8.3$ & 72 & $12.7 \pm 3.2$ & 77 & $10.1 \pm 3.4$ & 63 \\
\hline NV-AD & $26.2 \pm 9.3$ & 72 & $22.4 \pm 7.2$ & 76 & $17.3 \pm 2.4$ & 63 \\
\hline Total & $118.0 \pm 14.9$ & 72 & $86.7 \pm 11.4$ & 76 & $68.9 \pm 9.6$ & 53 \\
\hline
\end{tabular}

$n$ : number.

TABLE II

Some life cycle characteristics of Rhodnius neivai at three different temperatures (mean \pm SE weeks)

\begin{tabular}{lccc}
\hline & $22^{\circ} \mathrm{C}$ & $27^{\circ} \mathrm{C}$ & $32^{\circ} \mathrm{C}$ \\
\hline Total adult mean longevity & $24.6 \pm 2.4$ & $36.6 \pm 2.7^{a}$ & $16.7 \pm 2.9$ \\
Adult maximum longevity & $49.0 \pm 4.1$ & $61.8 \pm 3.4^{a}$ & $43.3 \pm 2.5$ \\
Life expectancy at the start of the egg stage & $28.2 \pm 3.4$ & $37.6 \pm 2.3^{a}$ & $19.0 \pm 3.8$ \\
Life expectancy when entering adult stage & $21.4 \pm 3.3$ & $34.2 \pm 2.1^{a}$ & $20.7 \pm 2.5$ \\
\hline
\end{tabular}

$a$ : significant difference. 

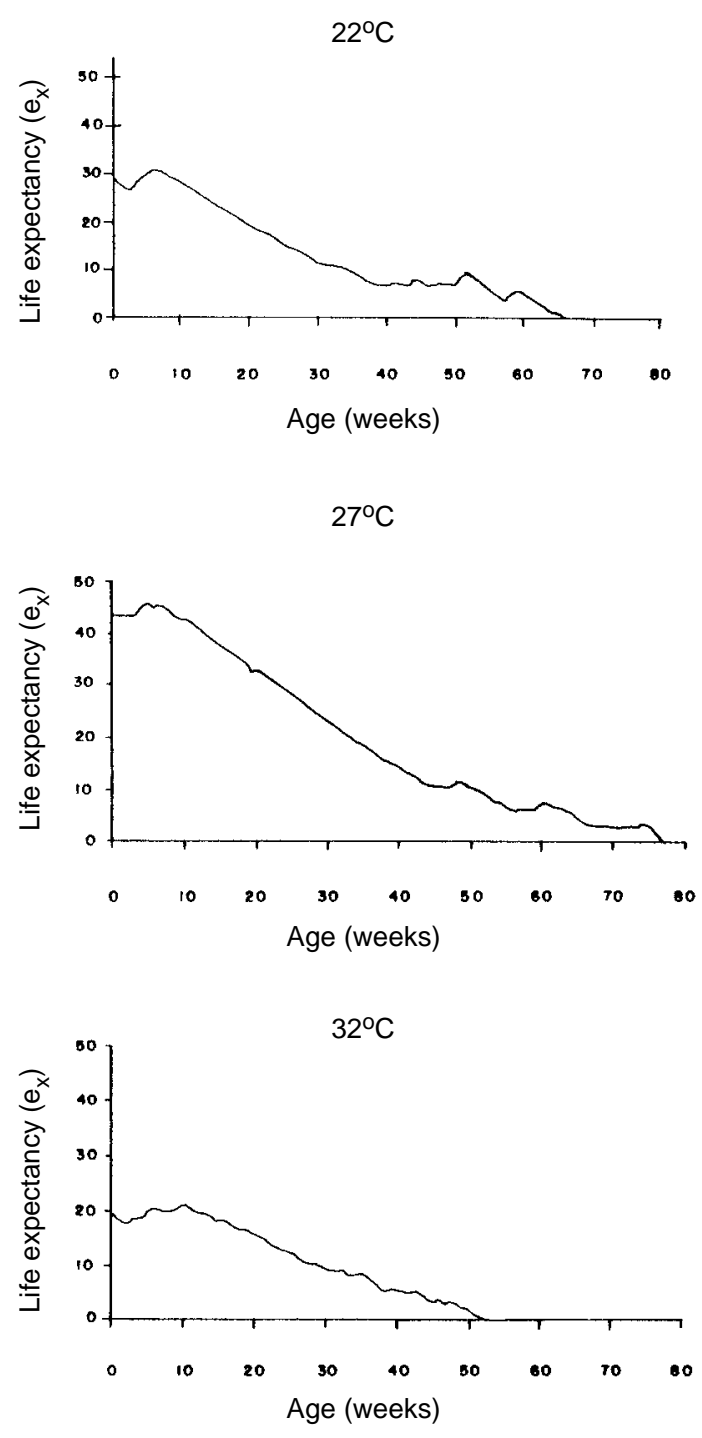

Fig. 1: life expectancy of Rhodnius neivai at three different temperatures.

age-specific schedule of mortality, until reaching zero at age of 68,79 and 53 weeks at $22^{\circ} \mathrm{C}, 27^{\circ} \mathrm{C}$ and $32^{\circ} \mathrm{C}$, respectively.

Reproduction - In Fig. 2, besides survival, average age-specific fertility $\left(\mathrm{m}_{x}\right)$, expressed as number of hatched eggs/female/week is presented. At $27^{\circ} \mathrm{C}$, a bell-shaped unimodal pattern, although irregular, curve was registered; reproductive peaks were at $28-35$ weeks of age. At $22^{\circ} \mathrm{C}$ and $32^{\circ} \mathrm{C}$, an unimodal general reproductive pattern, although less irregular, curve was also registered; reproductive peaks were at 28 and 17 weeks of age, respectively.

On any temperature, oviposition started with high values and kept them for several weeks, then
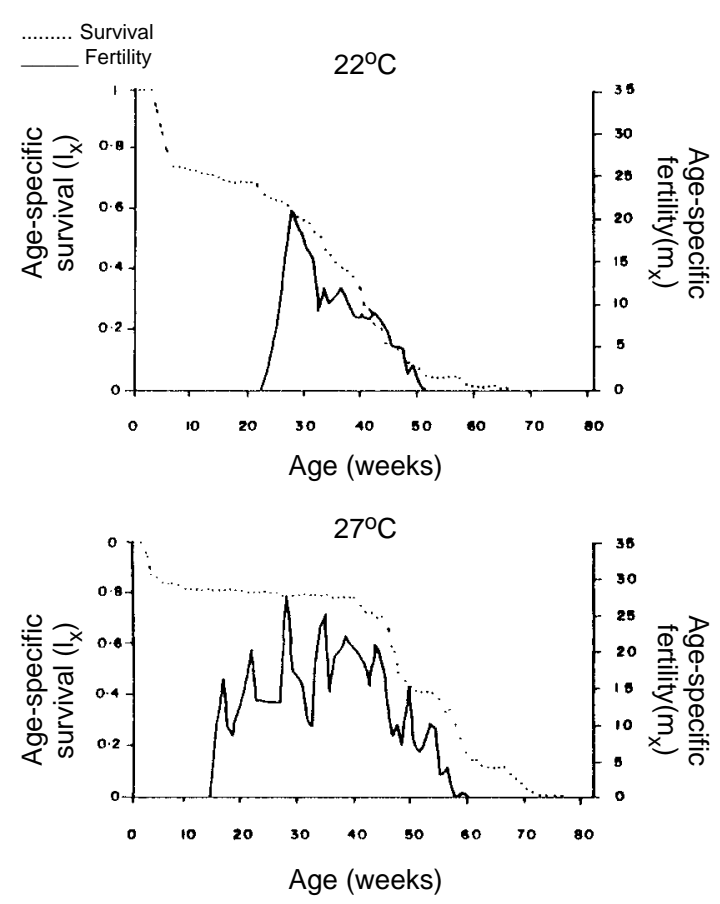

$32^{\circ} \mathrm{C}$

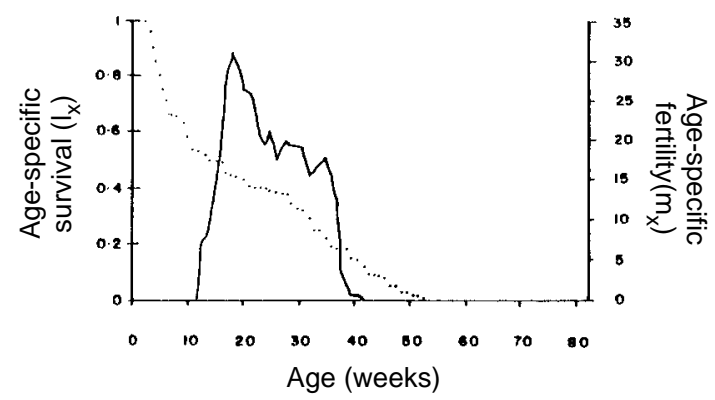

Fig. 2: survivorship and fecundity curves of Rhodnius neivai at three different temperatures.

dropped to lower levels with small rises until females stopped laying some 15 weeks before death of last adult, at 52,61 and 42 weeks, at $22^{\circ} \mathrm{C}, 27^{\circ} \mathrm{C}$ and $32^{\circ} \mathrm{C}$, respectively. At $32^{\circ} \mathrm{C}$, reproductive period finished more abruptly than at the others temperatures. Average hatching (fertility) for all cohorts was over $90 \%$. Survival during embryonic development was not affected neither by temperature nor by the age of the female parent.

Reproductive characteristics - A high negative correlation $(r=-0.84)$ was registered between temperatures and age of first reproduction. Age of maximum reproduction was significantly lower at $32^{\circ} \mathrm{C}$. Age of first laying after entering to adult stage was significantly higher at $22^{\circ} \mathrm{C}$. Average number of eggs/female/week and of eggs for female on its lifetime were significantly lower at 
$22^{\circ} \mathrm{C}$. Total number of eggs produced for the cohort and total number of reproductive weeks were significantly higher at $27^{\circ} \mathrm{C}$ (Table III). No significant differences were registered in sex rate and percentage of hatching.

Life tables and population statistics - The age specific mortality schedule provided the necessary data for construction of life tables. The statistics of population characteristics are summarized in Table IV.

Reproductive value - In Fig. 3 the average agespecific reproductive value $\left(\mathrm{V}_{x}\right)$ is shown. On the three temperatures, it changed with age and followed typical bell-shaped curves with its peaks occurring a few weeks after the start of the reproductive periods. It was higher and longer at $27^{\circ} \mathrm{C}$. Greater values were registered at 28, 21-37 and 17 weeks of age at $22^{\circ} \mathrm{C}, 27^{\circ} \mathrm{C}$ and $32^{\circ} \mathrm{C}$, respectively.
Thereafter, these values declined with a abrupt slope until the end of the generation. Table $\mathrm{V}$ shows, for each temperature, the reproductive values grouped by developmental stages. At $27^{\circ} \mathrm{C}$ and $32^{\circ} \mathrm{C}$, eggs and the three first nymphal instars made significantly lower contributions to cohort total reproductive value than in cohorts kept at $22^{\circ} \mathrm{C}$. At $32^{\circ} \mathrm{C}$, 5th nymphal instar made a significantly smaller contribution than the cohorts kept at $22^{\circ} \mathrm{C}$ and $27^{\circ} \mathrm{C}$. On any temperature adults made the greatest contributions and eggs and nymphal instars carried only less than $6 \%$ out of the total reproductive value of the cohorts.

\section{DISCUSSION}

In evaluating the results, we have taken into account the aspects of cohort study indicated by Rabinovich (1972a).

TABLE III

Reproductive characteristics of Rhodnius neivai at three different temperatures (mean $\pm \mathrm{SE}$ )

\begin{tabular}{lccc}
\hline & $22^{\circ} \mathrm{C}$ & $27^{\circ} \mathrm{C}$ & $32^{\circ} \mathrm{C}$ \\
\hline Age of first reproduction (weeks) & $22.1 \pm 1.6$ & $15.2 \pm 0.7$ & $12.5 \pm 0.7$ \\
Age of maximum reproduction (weeks) & $29.3 \pm 2.5$ & $30.5 \pm 3.5$ & $18.5 \pm 3.7^{a}$ \\
Age of first laying (days) after entering to adult stage & $27.4 \pm 1.8^{a}$ & $12.3 \pm 0.3$ & $13.5 \pm 1.2$ \\
Average number eggs/female/week & $11.1 \pm 1.2^{a}$ & $14.5 \pm 0.9$ & $17.7 \pm 2.4$ \\
Average number eggs/female/week at age of maximum reproduction & $21.4 \pm 2.7^{a}$ & $27.7 \pm 1.5$ & $31.5 \pm 2.1$ \\
Average number of egg for female on its lifetime & $264 \pm 57^{a}$ & $724 \pm 79$ & $603 \pm 49$ \\
Total number of reproductive weeks & $30.3 \pm 2.7$ & $46.7 \pm 1.8^{a}$ & $29.1 \pm 3.2$ \\
Number of eggs for cohort & $5497 \pm 308$ & $18140 \pm 439^{a}$ & $8676 \pm 356$ \\
$\%$ hatching & $89.0 \pm 2.4$ & $92.3 \pm 1.8$ & $96.1 \pm 0.9$ \\
Sex ratio (\% ) & $52.2 \pm 3.4$ & $48.6 \pm 2.2$ & $47.2 \pm 2.7$ \\
\hline
\end{tabular}

$a$ : significant difference.

TABLE IV

Population statistics of Rhodnius neivai at three different temperatures (mean $\pm \mathrm{SE}$ )

\begin{tabular}{lccc}
\hline & $22^{\circ} \mathrm{C}$ & $27^{\circ} \mathrm{C}$ & $32^{\circ} \mathrm{C}$ \\
\hline Generational time $(\mathrm{G})($ weeks) & $32.6 \pm 1.6$ & $32.9 \pm 1.1$ & $22.0 \pm 2.1^{a}$ \\
Net reproduction rate $\left(\mathrm{R}_{0}\right)$ & $114.6 \pm 11.7$ & $374.4 \pm 16.4^{a}$ & $142.4 \pm 13.2$ \\
Intrinsic rate of increase (r) & $0.14 \pm 0.03^{a}$ & $0.25 \pm 0.05$ & $0.22 \pm 0.03$ \\
Instantaneous birth rate (b) & $0.27 \pm 0.03$ & $0.32 \pm 0.02$ & $0.28 \pm 0.04$ \\
Instantaneous death rate (d) & $0.13 \pm 0.01^{a}$ & $0.07 \pm 0.03$ & $0.06 \pm 0.01$ \\
Finite rate of increase $(\lambda)$ & $1.16 \pm 0.02^{a}$ & $1.28 \pm 0.01$ & $1.25 \pm 0.03$ \\
Finite birth rate $(B)$ & $0.29 \pm 0.01^{a}$ & $0.36 \pm 0.05$ & $0.32 \pm 0.04$ \\
Total reproductive value $(\mathrm{V})$ & $1674 \pm 257$ & $2946 \pm 333^{a}$ & $2290 \pm 208$
\end{tabular}

$a$ : significant difference.

$$
\mathrm{R}_{0}=\underset{\alpha}{\sum 1_{x}} \mathrm{X} \mathrm{m_{x }} \quad \stackrel{\omega}{\sum_{\alpha}(x} \mathrm{X} 1_{x} \mathrm{X} \mathrm{m_{x } ) / \mathrm { R } _ { 0 }}
$$

$x$ : age; $\alpha$ : age of first reproduction; $\omega$ : age of last reproduction; $1_{x}$ : age specific survival; $\mathrm{m}_{x}$ : age specific fertility. 

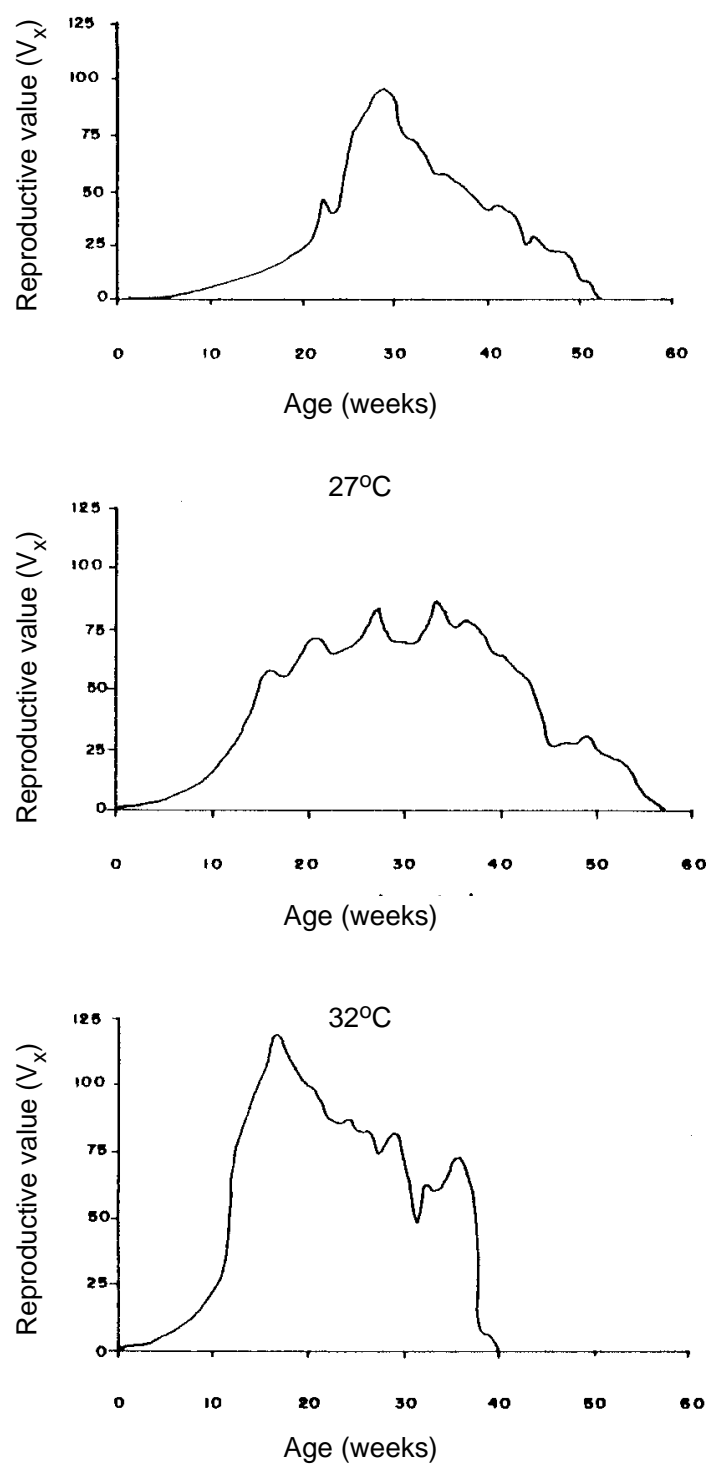

Fig. 3: age specific reproductive value of Rhodnius neivai at three different temperatures.
Life expectancy - The initial increase observed at $22^{\circ} \mathrm{C}$ and $27^{\circ} \mathrm{C}$ could be interpreted as the result of having overcome the largest mortality risks of first stages of life cycle, as egg hatching and first molting. On the other hand, at $32^{\circ} \mathrm{C}$ molting would be a larger mortality risk since life expectancy of adult stage was higher than at egg stage.

Survival - The survivorship curves (Deevey 1947) resemble a type I curve at $27^{\circ} \mathrm{C}$ and a type II curve at $22^{\circ} \mathrm{C}$ and $32^{\circ} \mathrm{C}$.

Reproduction - First laying occurs about 1213 days after molting to adults at $27^{\circ} \mathrm{C}$ and $32^{\circ} \mathrm{C}$ and after 27.4 days at $22^{\circ} \mathrm{C}$, corresponding to the indicated by Usinger (1944) and Hays (1965) who reported that females of triatomines start laying between nine days and four weeks after molting to adults.

In general, cohorts reared at $22^{\circ} \mathrm{C}$ started reproduction and reached the age of maximum reproduction later. Individual and total females laid less eggs for a shorter period. Consequently they had a lower reproductive output than those kept at $27^{\circ} \mathrm{C}$ and $32^{\circ} \mathrm{C}$.

Life tables and population statistics - Generation time varied between $22\left(\right.$ at $\left.32^{\circ} \mathrm{C}\right)$ and 33 weeks (at $22^{\circ} \mathrm{C}$ and $27^{\circ} \mathrm{C}$ ), this latter value is in line with the indicated for other species of triatomines, but the former is significantly lower, showing that at $32^{\circ} \mathrm{C}$ the actual mean length of a generation in terms of population dynamics is very short. Intrinsic rate of natural increase was significantly lower at $22^{\circ} \mathrm{C}$, but it could be due to the high instantaneous death rate at this temperature, since the instantaneous birth rate did not show significant differences at any temperature. Finite rate of increase was very similar to the observed in other species of triatomines; these two increase rates provide estimates of the growth potential of $R$. neivai populations. These growth rates may be similar to those in the field because there were density effects operating in the cohort jars. Net reproductive rate was significantly higher at $27^{\circ} \mathrm{C}$ suggesting that this is

\section{TABLE V}

Importance of the developmental stages of Rhodnius neivai in terms of reproductive value, as a percentage of the total reproductive value of the cohort, given in Table IV, at three different temperatures $($ mean \pm SE)

\begin{tabular}{lccc}
\hline Developmental stage & $22^{\circ} \mathrm{C}$ & $27^{\circ} \mathrm{C}$ & $32^{\circ} \mathrm{C}$ \\
\hline Egg & $0.24 \pm 0.06^{a}$ & $0.09 \pm 0.04$ & $0.11 \pm 0.03$ \\
1st nymph & $0.43 \pm 0.11^{a}$ & $0.07 \pm 0.02$ & $0.19 \pm 0.05$ \\
2nd nymph & $0.75 \pm 0.23^{a}$ & $0.21 \pm 0.03$ & $0.17 \pm 0.05$ \\
3rd nymph & $0.71 \pm 0.21^{a}$ & $0.16 \pm 0.02$ & $0.24 \pm 0.07$ \\
4th nymph & $0.96 \pm 0.32$ & $0.80 \pm 0.12$ & $0.73 \pm 0.19$ \\
5th nymph & $3.00 \pm 0.84$ & $2.63 \pm 0.61$ & $1.25 \pm 0.46^{a}$ \\
Adult & $3.90 \pm 6.14$ & $96.00 \pm 9.47$ & $97.30 \pm 9.32$
\end{tabular}

$a$ : significant difference. 
the optimal temperature for rearing this species. However, all values were considerably higher than the reported by Rabinovich (1972b) in R. prolixus: 49.03, Feliciangeli and Rabinovich (1985) in $T$. maculata: 86.21 and Guarneri et al. (1998) in $R$. domesticus: 70.4 , probably due to the greatest feeding frequency in this experiment. Total reproductive value was also significantly higher at $27^{\circ} \mathrm{C}$, because of its longer reproductive period and the higher values of its average number of eggs/female/ week during longer periods. The reproductive value should be grouped by developmental stages since these figures indicate how much each instar is worth in terms of offspring it will contribute to the next generation (Wilson \& Bossert 1971). With the exceptions of the $3 \mathrm{rd}$ nymphal instar at $22^{\circ} \mathrm{C}$, the 1 st and the $3 \mathrm{rd}$ nymphal instar at $27^{\circ} \mathrm{C}$, and the 2nd nymphal instar at $32^{\circ} \mathrm{C}$, which have larger values than the preceding instars but smaller than the succeeding ones, there is a trend of increasing reproductive value as the individuals advance in their development.

\section{ACKNOWLEDGMENTS}

To the anonymous reviewers whose suggestions improved the original manuscript.

\section{REFERENCES}

Birch LC 1948. The intrinsic rate of natural increase of an insect population. J Anim Ecol 17: 15-26.

Cabello DR, Lizano E, Valderrama A 1987. Estadísticas vitales de Rhodnius neivai Lent, 1953 (Hemiptera: Reduviidae) en condiciones experimentales. Mem Inst Oswaldo Cruz 82: 511-524.

Deevey ES 1947. Life tables for natural populations of animals. Quart Rev Biol 22: 283-314.

Dublin LI, Lotka AJ, Spiegelman M 1949. Length of Life (Rev. Edit.), Ronald Press, New York, 157 pp.

Feliciangeli MD, Rabinovich JE 1985. Vital statistics of Triatominae (Hemiptera: Reduviidae) under labora- tory conditions. II. Triatoma maculata. J Med Ent 22: 43-48.

Fisher RA 1930. The Genetical Theory of Natural Selection, Claredon Press, Oxford, 268 pp.

Gómez Nuñez JC, Fernández J 1963. La colonia de Rhodnius prolixus en el Instituto Venezolano de Investigaciones Científicas. Bol Dir Malariol y San Amb 3: 132-137.

Guarneri AA, Carvalho Pinto CJ, Schofield CJ, Steindel M 1998. Population biology of Rhodnius domesticus Neiva \& Pinto, 1923 (Hemiptera: Reduviidae) under laboratory conditions. Mem Inst Oswaldo Cruz 93: 273-276.

Hays KL 1965. Longevity, fecundity and food intake of adult Triatoma sanguisuga (LECONTE) (Hemiptera: Triatominae). J Med Ent 2: 200-202.

Lent H, Jurberg J 1969. Observações sobre o ciclo evolutivo em laboratório do Panstrongylus geniculatus (Latreille, 1811) (Hemiptera: Reduviidae: Triatominae). An Acad Brasil Cienc 41: 125-131.

Lent H, Wygodzinsky P 1979. Revision of the triatominae (Hemiptera: Reduviidae), and their significance as vectors of Chagas' disease. Bull Am Mus Nat Hist 163: 123-520.

Machado-Allison CE, Ramírez-Pérez J 1967. Chipos, Cuadernos Científicos, 1a. serie, No. 2, Dirección de Cultura, Universidad Central de Venezuela, Caracas, $52 \mathrm{pp}$.

Rabinovich JE 1972a. Vital statistics of Triatominae (Hemiptera: Reduviidae) under laboratory conditions. I. Triatoma infestans Klug. J Med Ent 9. 351-370.

Rabinovich JE 1972b. Vital statistics of Triatominae (Hemiptera: Reduviidae) under laboratory conditions. II. Rhodnius prolixus Stal, p. 291, Abst 14th Intern Congr Entomol, Camberra.

Usinger RL 1944. The Triatominae of North and Central America and the West Indies and their significance. Publ Hlth Bull 288: 1-83.

Wilson EO, Bossert WH 1971. A Primer of Population Biology, Sinauer Associates, Inc. Publishers, Stanford, $192 \mathrm{pp}$. 